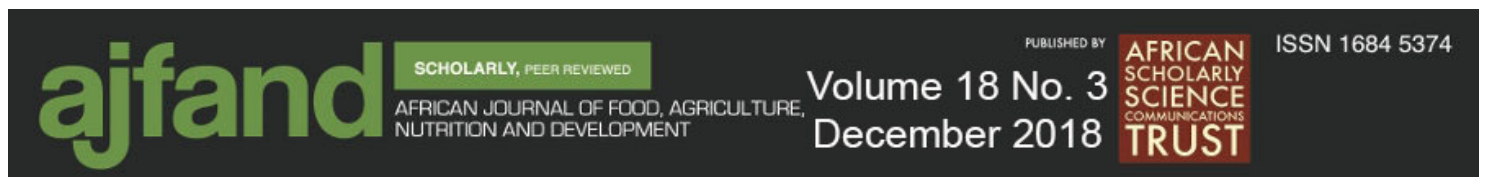

Afr. J. Food Agric. Nutr. Dev. 2018; 18(3): 13776-13791

DOI: 10.18697/ajfand.83.17215

\title{
CONSIDERATIONS FOR THE SHIFT IN ROLES OF NATIONAL AND COUNTY GOVERNANCE TOWARDS THE REALIZATION OF FOOD SECURITY IN KENYA
}

Wafula EN $^{1 *}$ and O Odula ${ }^{2}$

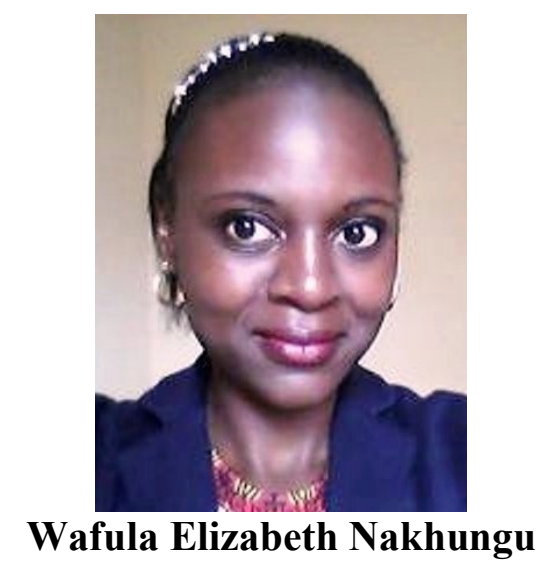

Corresponding author email: elizabethwafula@jkuat.ac.ke

${ }^{1}$ Department of Food Science and Technology, School of Food and Nutritional Sciences, College of Agriculture and Natural Resources, Jomo Kenyatta University of Agriculture and Technology, P.O. Box 62, 000-00200, Nairobi, Kenya

${ }^{2}$ Institute of Horticultural Production Systems, Section of Vegetables Systems ModellingGottfried Wilhelm Leibniz Universität, Herrenhäuser Straße, 2, 30419 Hannover, Germany 


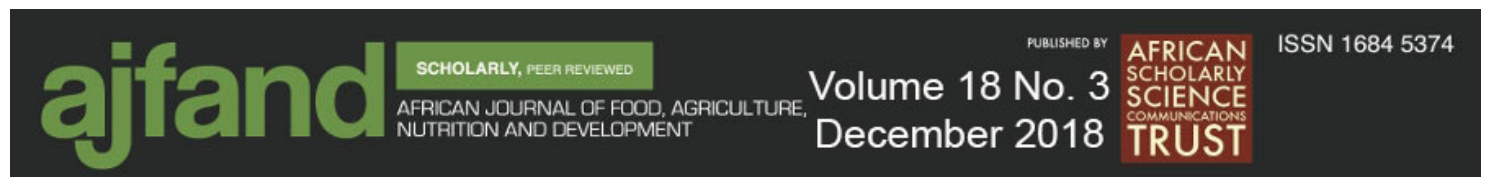

\begin{abstract}
The international community's view on the state's role in a country's development and by extension food security situation is currently very positive. As a means to improve governance, decentralization in its many forms is being advocated all over the world. In August of 2010, Kenya embraced a new system of governance which involved the devolution of the central government and public participation as its new and critical components. This implied a shift in the roles of national and county governance towards the achievement of food security. Since food security is a multi-dimensional phenomenon, it is affected by many factors including governance. Thus, the government among other actors, plays a critical role in the achievement of food security. The scope of this review was 'Good Food Security Governance' within the national context, specifically focusing on the two tiers of government; national and county. This study aimed to call to attention the areas under governance in need of special attention by outlining the history of Kenya's political economy that has contributed to the current state of food insecurity. It also seeks to reinforce government's role in food security and propose possible key roles the national and county governments could embrace towards the realization of food security. There is need to eradicate corruption, streamline land tenure systems through effective land reforms, strengthen institutions that were weakened during former government regimes and empower county governments. The role of governments at both county and national level in food security should be reinforced by viewing food security as a public good and on the basis of the right to food as stipulated in the constitution of Kenya. While the national government needs to focus on capacity building of county governments, spurring economic growth, aiding poor rural farmers and putting in place social safety nets, the county government's role should be the identification and implementation of context-specific integrated approaches to improve food security of their peoples. In conclusion, if these considerations are to be properly addressed then governance for food security in Kenya can be improved.
\end{abstract}

Key words: Kenya, Governance, Decentralization, Roles, Food Security, Political Economy, County 


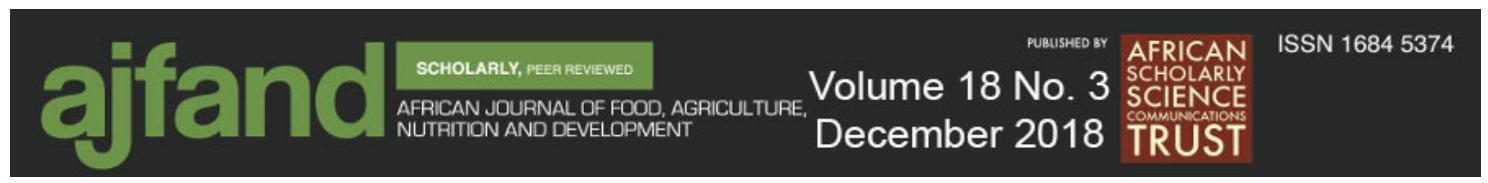

\section{INTRODUCTION}

Increasing attention has been given to the quality of governance; governments' ability to make and enforce rules and to deliver services $[1,2]$. Persistent development failures in developing countries led to the intellectual reawakening of the role of the state $[3,4]$. The state was no longer viewed as a threat, but as essential to provide an enabling environment for development [4]. This realization has led to crucial questions. Are the deficiencies in governance the root causes of underdevelopment in sub-Saharan Africa? Will solving the problem of 'poor governance' lead to better food security outcomes for the region's populations? The 1989 World Bank Report, 'Sub-Saharan Africa: From Crisis to Sustainable Growth', cites weaknesses of governance in Africa as the central causes for underdevelopment [5]. Contrary to this strong view, is the fact that governance requires resources and most countries in sub-Saharan Africa have inadequate domestic resources. It follows that poor countries will have poorer governance measures. Even if the governance of poor countries is relatively good, major investment in public goods will be required to move these countries from the poverty trap [6]; an underlying cause for widespread food insecurity. Therefore, improvement of governance is not the entire solution but can be a contributing factor to the achievement of food security.

A workshop on 'Good Food Security Governance: The Crucial Premise to the Twin Track Approach' held at Food and Agricultural Organization (FAO), Rome in 2011 can help to shed light on the role of governance in the food security of a country. It was increasingly believed that standard technical assistance including building capacity and providing support to food security-related initiatives as a response to food insecurity was not sufficient. Failure of governance was seen as the reason why millions of people are still food insecure. Food security governance has mainly been left in the hands of the global community. However, it should be noted that there is a gap. The question of accountability in as far as ensuring that every global citizen has food is yet to be answered. For this lack of accountability is the need to look into how governance within a country is contributing to, and can contribute to its state food security/insecurity [7].

Inefficiency, corruption and unaccountability characterize poor governance of unresponsive and poorly functioning states. This has caused dissatisfaction among the international community and people in developing countries who want change [3]. As a result, there has been a push for decentralization as a way of trying to advocate for better governance [8]. Efficiency is the basis for leading propositions for devolution. It is expected that decentralizing functions to lower levels of decision making will make better use of information at the local level and reduce transaction costs. Looking at Kenya's political economy history, deficiencies in government led to wide socioeconomic inequalities that fueled the demand for devolution. Accordingly, in 2010, after the new constitution was instated through a national referendum, devolution resulted in the formation of a national government and 47 county governments. This saw Kenya leave behind its unitary state system [9]. The hope was that devolution would bring positive change extending to the country's food security situation.

The scope of this review is governance for food security at the country level. It seeks to emphasize how the context (socio-political) in which the devolved governance system 


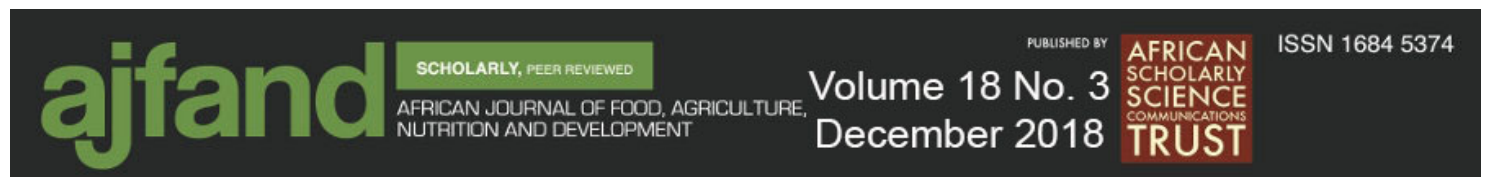

was established exacerbated the food security situation. By highlighting deficiencies in governance and proposing clear governance roles, an understanding of the demands and constraints to respond to for food security to be realized can be arrived at.

\section{METHODOLOGY}

\section{Conceptual Framework: FAO's Good Food Security Governance}

This review was based on FAO's Good Food Security Governance Framework. This is a guide for analyzing and understanding weaknesses in the food security governance in a given country. Good food security governance constitutes an enabling environment that allows the twin track program (access to food and investment in development, particularly support to agriculture) to become effective. A proposed definition for "good food security governance" is "the formal and informal rules and processes through which interests are articulated, and decisions relevant to food security in a country are made, implemented and enforced on behalf of members of a society", [7, p 17].

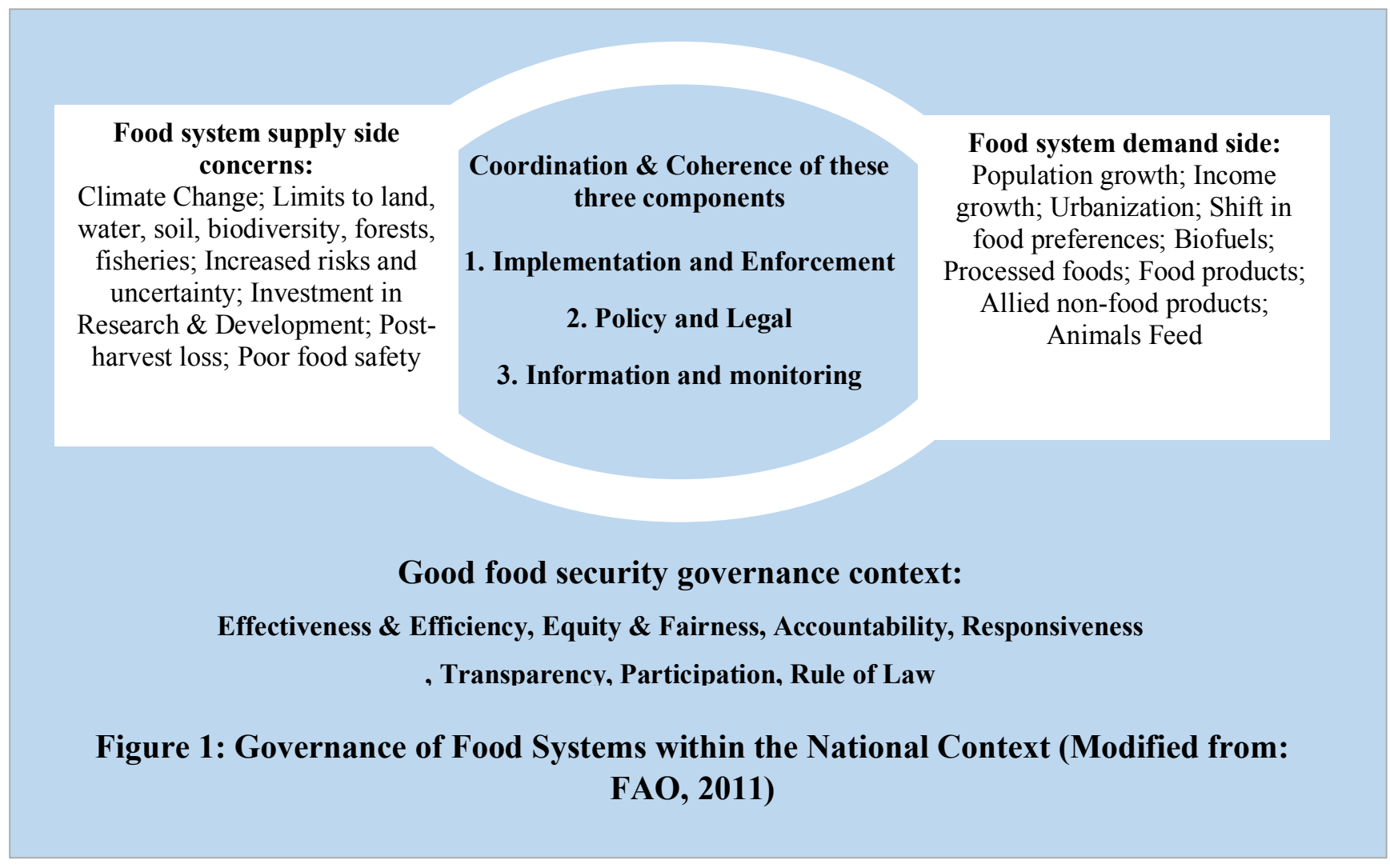

The framework is organized in four different levels: Policy and legal framework includes the visions, goals and priorities, cross-cutting strategies, laws and programs and actions, Coordination and coherence between policies, intra- and inter-agencies and multiple actors involved, Implementation and enforcement considers institutional capacity, roles and responsibilities, service delivery, accountability and recourse mechanisms, Information, monitoring and evaluation of assessments, data management, progress of activities, achievements and impacts. There are two operational guidelines in the 


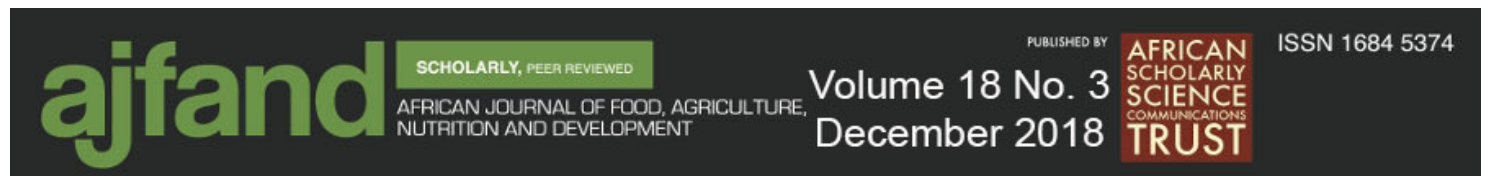

framework: 1) Looking at the context based on food security governance quality dimensions of efficiency and effectiveness, equality and fairness, accountability, responsiveness, transparency, participation and rule of law, 2) Applying the relevant quality dimensions throughout the different levels of the framework [7].

This review explored the context of food security governance. While trying to understand food security governance, it is imperative to look at both broad socio-political context and the specific political context. Political governance including effective separation and balance of powers, general public resources management and independence of the judiciary is beyond the mandate of food security planners. However, it could impact the progress towards improved food security governance. All countries have agricultural and food security policy regimes developed in response to particular historical socioeconomic and political challenges. This is why the historical perspective on the political economy of Kenya is initially discussed. Responsibility allocation in the implementation and enforcement of food security actions, policies and interventions by the devolved government is suggested to foster the inclusion of food security quality dimensions. Important outcomes of good food security governance entail effective policy instruments and actions for achieving food security, administrative capacity, strong and capable civil society and the respect for the rule of law [7].

\section{Data Collection}

Secondary sources of data were used. These were peer reviewed publications obtained using web of science and Google scholar search engines and grey literature from governmental and inter-governmental organizations, World Bank and FAO.

\section{Data Analysis}

General inductive approach to data analysis was adopted [10]. The sources of data were read severally to understand meanings. Meaning condensation and meaning characterization was applied to the data. Specific text segments were identified relating to the conceptual framework. Data was then categorized according to topics.

\section{RESULTS AND DISCUSSION}

\section{KENYA'S FOOD SECURITY SITUATION}

This brief synopsis of the food security situation within the country points to a positive trend, but there is still much to desire. Stunting (chronic malnutrition), wasting (acute/recent malnutrition) and underweight in children under five reduced from $35 \%$, $7 \%$ and $20 \%$ in $2008 / 2009$ to $26 \%, 4 \%$ and $11 \%$ in 2014 , respectively $[11,12]$. The global hunger index, a composite indicator based on undernourishment, child wasting, and child mortality, improved from 29.8 in 2008 to 21.0 in 2017. However, the country situation is still classified as serious [13]. At the level of the household, $12 \%$ of Kenyan households continue to experience poor dietary diversity [12]. The percentage of household experiencing severe food insecurity has been reported to be high especially during the dry seasons [14]. Approximately, 7.5 million Kenyans are chronically food insecure with 2 to 4 million requiring food assistance $[15,16]$. Particularly people living in the arid and semi-arid regions of the country such as Turkana and North Rift Valley 


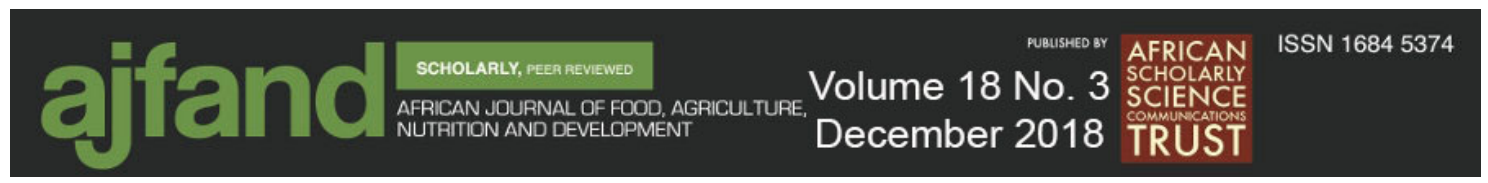

which are not suitable for rain-fed agriculture, are prone to droughts and continue to experience conflict $[16,17]$.

\section{HISTORICAL PERSPECTIVE ON THE POLITICAL ECONOMY OF KENYA: CAUSES OF FOOD INSECURITY}

An analysis of the history of Kenya's political economy raises a number of pertinent issues in governance that have adversely affected food security in the country. They include inequality in land tenure, corruption, centralization of power and weak/inappropriate institutions due to government capture by the political elite. Therefore, whether devolution will be able to deliver the realization of food security in Kenya depends on its ability to address these issues.

\section{Inequalities in land tenure due to inappropriate land reforms}

The ability to access and utilize land is context specific and affects food security in African countries. Most economies depend on land-based activities such as agriculture which is directly linked to, and mining and tourism which are indirectly linked to food security [18]. The agricultural sector is the mainstay of Kenya's economy; land plays a significant role in the socio-economic and political development of the country. Its ownership, allocation, distribution and utilization is of great concern to most Kenyans [19].

The lack of access to land and growing inequality in land ownership contribute to high levels of impoverishment and food insecurity in Kenya [19]. This is attributed to land reforms characterized by a lack of meaningful redistribution that have roots in preindependent Kenya. Even after independence, successive governments failed to instate appropriate land reforms. Instead they used land as a source of patronage to gain political support [20]. The current land reforms in Kenya enhance land owners' rights which are important for productivity and efficiency. However, the country is still grappling with high unemployment, landlessness, unequal distribution of land, unsustainable land subdivision and conversion of arable land to built-up environment. In such cases, land reforms involving actual redistribution of land while strengthening ownership rights are necessary and have led to undeniable gains in food security in other contexts [21].

Due to inequalities in land ownership, most farming in Kenya is done by small-scale farmers. These farmers' lands could be over-utilized and degraded, which is not uncommon, thus they might not be able to feed themselves [18]. This stresses the importance of access to markets for additional food and essential non-food needs [21]. Therefore, poor market integration strengthens the links between household food production and food security [21]. On the other hand, if large-scale export farming creates many well-paying jobs, then it can improve food security. If it is capital intensive or pays low wages, it may not have a positive effect for the poor [18].

Development and grass root organizations such as small farmer associations, agricultural labour unions and women's and indigenous groups can play a critical role in supporting rural economies through improving land tenure systems and working conditions of communities [22]. An example is the Oasis Development Group in Kenya which assisted 


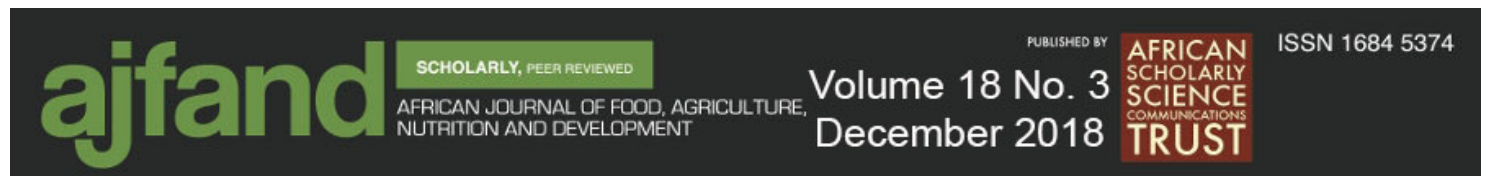

in preventing the unjust eviction of the Doroboi people from forest land being appropriated by a government project. Development programs should also be chosen carefully as demonstrated by the Mwea irrigation scheme project in central Kenya. Farmers were forced to produce rice only to realize that it was not as profitable as expected and the introduction of water to the lands led to a marked increase in the incidence of waterborne diseases [18].

\section{Corruption}

Corruption in Kenya was reported to be so endemic as to threaten the basic structures of the state [20]. Corruption compromises the quality of government intervention which is required especially in cases where markets are unable to deliver food security by themselves [19]. In a case of decentralization, there runs a risk of corruption practices being transferred from the national to the devolved levels by the sub-national elites. Will this then represent a net saving or cost for service delivery? [9].

Countries that have well developed governance structures have achieved better levels of food and nutrition security because they are less susceptible to corruption. When the poor have opportunities to exercise their political and civil rights, governments are more attuned to their needs and demands, and among other effects, are more likely to focus on better allocation and use of resources for food security programs [23]. Improved governance of public distribution system of food has translated to better food security. Inclusivity, participatory management and transparent administrative practices, monitoring the movement of food supplies to curb diversion into the black markets, proper mechanisms for addressing grievances and fixed distribution schedules were incorporated into the system. These resulted in structural improvements, better coverage of eligible beneficiaries, minimal targeting errors and reduced diversion of grains as well as reduced calorie deficiency. The end result was increased demand for the services from the public [1].

\section{Centralization of Power}

In the 1970's and 1980's, the central government slowly cut its resource base and powers of local governance by transferring responsibilities such as service provision to line ministries. The presidency took on extra powers while simultaneously weakening checks; institutions such as the judiciary, auditor general and systems of financial management, tactics employed to weaken political opponents [17, 20]. Given that local governance level had been compromised, of concern is the technical capacity to deliver the much needed public goods that will ensure that food security is achieved and sustained in the short and long term. An enabling environment is required for the provision of civil peace, rule of law, rural roads, agricultural extension and public research to generate new productivity to ensure adequate governance for food security. Public delivery at the national level has been less than adequate in Sub-Saharan Africa. There is need to evaluate whether this problem is being solved or whether inefficiencies are simply being decentralized. Decentralization cannot be a solution to inefficiencies of service provision at the central level if their root causes are not well understood [9]. 


\section{Weak/Inappropriate institutions}

Institutions are important in determining the subsequent market and environmental outcomes [8]. Historic patterns of policy making in agricultural development have persisted in Kenya despite widespread recognition that they have generated sub-optimal growth and poverty reduction. This is in spite of a bold strategy (Strategy for Revitalizing Agriculture, SRA) that had presidential backing to change them. Why is it so in a democracy, which in theory should strengthen the poor, rural majority in the country [24]? It followed that challenges of food insecurity, wide spread poverty and poor agricultural output still remained. The SRA was succeeded by the Agriculture Sector Development Strategy (ASDS) that was formulated on the basis of vision 2030. This policy aims to ensure food and nutritional security and $10 \%$ annual economic growth rate [25]. Also, the Food Security Act of 2014, the National Food and Nutrition Security Policy, the Constitution of Kenya and the recently launched Big Four are all positive attempts in Kenya's effort to solve the rampant food insecurity. They shift the government's narrative from a mainly production approach (hinged on major food/cash crops) to a rights-based approach seeking to solve food insecurity and malnutrition by integrating governance at both national and county levels. Elements of participation, transparency and accountability to offer inclusive solutions to vulnerable, minority and marginalized groups' food security problems are included [26, 27, 28].

For these institutions (agricultural and food security policies and the constitution) to be successful, inadequate grass-roots institutions to foster and promote innovative practices, deficient extension services, the poor state of transport and other infrastructure, high transaction costs, and lack of accountability need to be addressed. Knowledge mobilization, research, and education need to be incorporated into sustainable food security policy. This can be achieved by improving communication between researchers, farmers and policy makers. The adoption and success of food security activities, interventions, policies and programs can be improved by taking into account; local innovation and technical knowledge, social relations, cultural norms and gender equity, environmental and natural resources, and small-scale holders' adversity to market and environmental risks [29].

To finalize this section, it should be called to attention that 'Sustained political commitment at the highest level is a pre-requisite for hunger reduction. It entails placing the food security and nutrition at the top of the political agenda and creating an enabling environment through adequate investments, better policies, legal frameworks, stakeholder participation and a strong evidence base' [30, p 1]. As such, the roles of national and county governance in food security should be reinforced and clearly defined.

\section{THE ROLES OF THE GOVERNMENT IN FOOD SECURITY}

Table (1) indicates the roles in food security of the national and county governments in Kenya.

\section{Reinforcing the Role of Governments in Food Security}

National or local food organizations, institutions, and markets shape a country's food system impacting on its food security. Challenges within food systems such as corruption, self-serving elite and inequality among others call for better local 


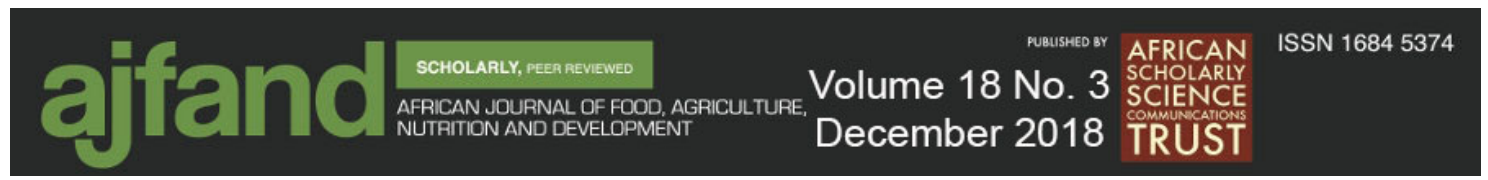

governance. National governments that have responded to the need for country level food security governance and sustainable political systems, have been able to obtain better food security welfare for its populations. Where response has been lacking, hunger persists [8].

Food insecurity results in significant negative consequences that adversely affect a country's people; malnutrition and negative health outcomes which reduce productivity hence economic returns, over exploitation of ecosystems, lowering the dignity and respect of people, and violence/conflict $[31,32]$. At the forefront pushing for eradication of food insecurity are global organizations that demonstrated inadequate and incoherent responses to crisis and non-governmental organizations with inadequate resources [31]. Most private institutions are unwilling to utilize resources in not-for-profit activities. Food security should therefore be viewed as a public good. Provision of public goods is the foremost task of the government at all levels [8].

Furthermore, the right to food holds states accountable for its progressive realization within their nations. States should establish appropriate institutional mechanisms particularly to identify emergency threats to the right to food as early as possible, 'improve coordination of different ministries at the national level and between national and county levels; improve accountability with a clear assignation of responsibilities; ensure adequate participation particularly of the food insecure segments of the population and; pay close attention to the need to improve the situation of the most vulnerable in society' [33]. Governments are however, faced with a challenge. The proliferation of organizations in the past years have resulted in multiple, alternative institutional frameworks that have weakened the state. This has led to ensuing power struggles making it difficult for governments to enact legislation or design policies that guarantee the right to food; this is the political economy problem of food insecurity [31]. In spite of this difficulty, governments need to step-up their efforts.

\section{Role of Governance at the National (Centralized) Level}

The essence of decentralization is that county governments be more responsive to the needs of their people. This does not mean the state should not play a minimalist role as put forward in classical neo-liberalism, but must ensure that its capacity to function is not diminished for two main reasons. It is likely that institutions of local democracy and mechanisms of political accountability are weak. Hence, discussions on public services delivery, policy and program design have to deal with issues of capture at the national and county governments by elite groups more seriously now, compared to the past, by the governments themselves and food security planners. The second concern has to do with technical and administrative capacity. It should be understood that information asymmetry can be present in two ways. While the central government may not know what to do, the county governments may not know how to do it. The national government needs to continuously upgrade personnel's knowledge, skills, and technical know-how at the county government level. This requires resources that county governments may not have, but the national government does [8].

The national government's specific approach in dealing with food security will depend on factors such as country context, the food security situation, public sector structure and 


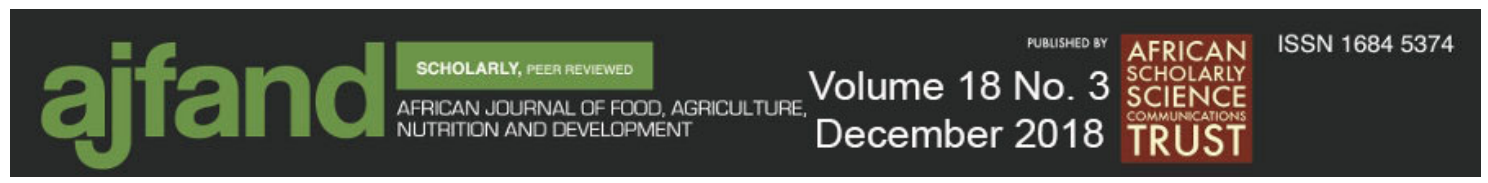

the amount of resources available [34]. The key elements of a food security strategy at the country level should include the following pillars.

First, the national government should consider strategies that will spur economic growth with the potential to generate employment and stimulate local markets. This is vital but not a sufficient way of tackling food insecurity. It has been demonstrated that economic growth especially in developing countries does not lead to immediate improvement of food security outcomes and incomes of the rural poor [34]. Kenya's Vision 2030 MTP III Strategy, is an example of a policy oriented towards the improvement of economic, social and political wellbeing of the citizens of Kenya. It aims to improve agricultural productivity and food security under its economic pillar [15].

Secondly, governments should help resource-poor smallholder farmers in rural areas help themselves. Productivity of such livelihoods, especially if it is for subsistence purposes, should be improved because this will increase access to foods. It can increase farmers' incomes should food be produced in surplus and sold. Several government-funded programs have been piloted towards assisting smallholder farmers to acquire inputs, access markets, and increase productivity [34]. These include National Agricultural Accelerated Inputs Program (NAAIAP), Kenya Agricultural Productivity and Agribusiness Project (KAPAP), Kenya Rural Development Program (KRDP) and Small Holder Marketing Program (SHOMAP) [15].

Third, the national government should provide basic social services and social safety nets to increase the resilience of the livelihoods of the most vulnerable by providing them with a diversity of coping strategies. These should not only protect incomes, health and assets but also expand development options [34]. Examples of safety nets in Kenya include Njaa Marafuku, which entails a conditional cash transfer program and a school feeding program and targets the poor and vulnerable in the community [15].

\section{Roles of Governance at the County Level}

County governments should provide integrated approaches to address the various issues that affect food security. Examples of such actions include: providing basic infrastructure that supports the production and distribution of food crops including roads, dams, wells, markets, extension services among others; dealing with land disputes, providing a forum for community groups participation and involvement in the food security agenda, providing necessary support for environment sustainability; better understand the needs of small-scale farmers as this information is key to the implementation of food security policies and information gathering, or in other words, building an evidence base that can help to understand local conditions affecting food security, including weather and cropping patterns, local trade flows, and lastly, synergies and causes of chronic and transitory food security [34]. 


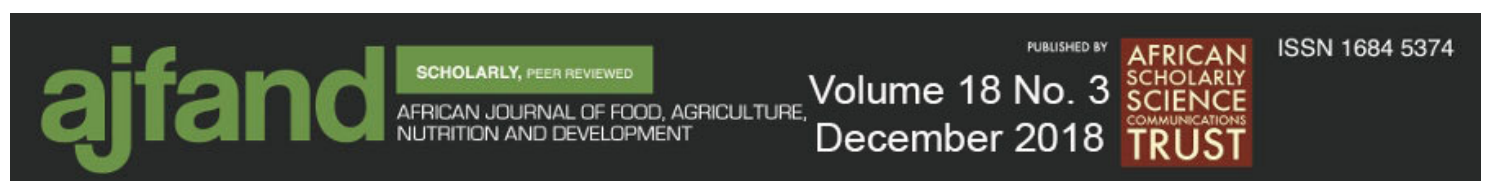

\section{CONCLUSION}

The government of Kenya already acknowledges the important role it plays towards the realization of food security within the country. However, socio-political bottlenecks including inequality of land tenure, corruption, deteriorated local governance capacity, and weak and inappropriate institutions need to be addressed if food security is to be achieved. Food security should be viewed as a public good as it is embedded in the right to food. Devolution should not be viewed as a way for national government to play a minimalist role because county governments require multilevel food security strategy facilitation, resources, and capacity building to carry out their roles effectively. It should be noted that there are limitations to decentralization of food security governance, especially since power and resource sharing, and communities' empowerment may not be acceptable to all parties. The study is limited in that it only focused on state actors yet food security governance also includes traditional and customary authorities, private and professional sectors and civil society organizations that also affect the adoption and implementation of food and nutrition security measures. Additionally, service provision roles and responsibilities allocation should be backed by empirical evidence and adequate assessment of who could handle a given type of service in the most effective and efficient way. There is a gap as no such studies have been done in Kenya this far.

\section{ACKNOWLEDGEMENT}

Professor George Andre Simone of Roma Tre University and Mr. Norman Messer of the International Fund for Agricultural Development (IFAD) provided their guidance and constructive criticism towards the initial development of ideas for this paper. 


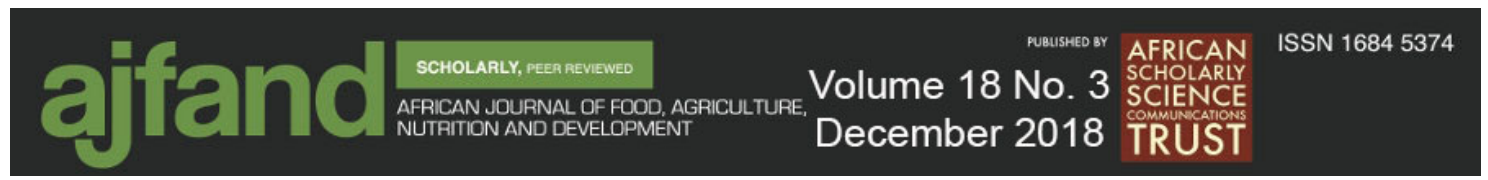

Table 1: The Functions of National and County Governments in Food Security in Kenya

\begin{tabular}{|c|c|}
\hline National Government & County Government \\
\hline - $\quad$ Capacity building $\&$ back stopping & $\begin{array}{l}\text { - Identification of manpower and } \\
\text { development of training needs. } \\
\text { - Mainstreaming of sociological } \\
\text { perspectives e.g. HIV/Aids, governance } \\
\text { in line with the national policy. } \\
\text { - Coordination of extension services and } \\
\text { staff training programmes. } \\
\text { - Identification and up scaling of } \\
\text { successful indigenous technical } \\
\text { knowledge. }\end{array}$ \\
\hline $\begin{array}{l}\text { Promotion of public/private partnerships } \\
\text { and national agricultural institutions. }\end{array}$ & \\
\hline $\begin{array}{l}\text { - Development and management of } \\
\text { projects and programmes. }\end{array}$ & $\begin{array}{l}\text { - Planning and implementation of county } \\
\text { specific projects and programmes. } \\
\text { - Mobilize resources for county specific } \\
\text { projects and programmes. } \\
\text { - Monitoring and evaluation. } \\
\text { - Enforcement and compliance of } \\
\text { standards and regulations. }\end{array}$ \\
\hline $\begin{array}{lll}\text { - } & \begin{array}{l}\text { Promotion } \\
\text { development. }\end{array}\end{array}$ of Agri-business & $\begin{array}{l}\text { - Promotion of farming as a business. } \\
\text { - Promotion of value addition and agro- } \\
\text { processing. }\end{array}$ \\
\hline - Implementation of land use policy. & $\begin{array}{l}\text { - Customization and implementation of } \\
\text { farm management guidelines. } \\
\text { - Catchment conservation. }\end{array}$ \\
\hline $\begin{array}{l}\text { - Policy and legislation formulation, } \\
\text { review and implementation. }\end{array}$ & $\begin{array}{l}\text { - Implementation of national and sectoral } \\
\text { policies and legislation. } \\
\text { - Formulation and review of county } \\
\text { specific policies and legislation. } \\
\text { - Participation in development of national } \\
\text { agriculture policies and strategies. }\end{array}$ \\
\hline & $\begin{array}{l}\text { - Organization and management of } \\
\text { agricultural resources in the counties for } \\
\text { example equipment, human resource, } \\
\text { finances etc. }\end{array}$ \\
\hline & $\begin{array}{l}\text { - Facilitation of research-extension-farmer } \\
\text { and other stakeholder linkages. }\end{array}$ \\
\hline & - Pet and disease control. \\
\hline & $\begin{array}{l}\text { - } \begin{array}{l}\text { Promote good post-harvest management } \\
\text { practices. }\end{array} \\
\end{array}$ \\
\hline & - Water harvesting and management. \\
\hline & - Generation of county research priorities. \\
\hline & - County specific disaster management. \\
\hline
\end{tabular}

Source: Memorandum to National Security Advisory Council (NSAC) by the cabinet secretary for agriculture, livestock and fisheries on the status of food security in the country in 2014 [35] 


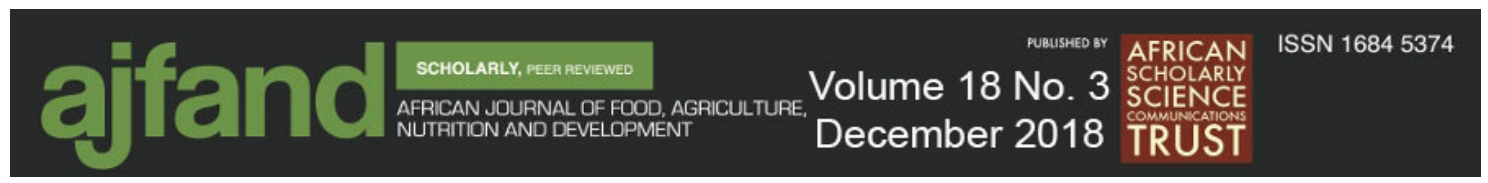

\section{REFERENCES}

1. Kumar A, Parappurathu S, Babu SC and PK Joshi Can better governance improve food security? An assessment of the public food distribution system in Odisha, India. F. Sec. 1-13.

2. Fukuyama F What is governance? GD Working Paper 314. Centre for Global Development, Washington D.C, 2013. Accessed on 11/12/2018 at: https://www.cgdev.org/sites/default/files/1426906_file_Fukuyama_What_Is_Gov ernance.pdf

3. Carothers T and de D Gramont Aiding Governance in Developing Countries Progress amid Uncertainties. The Carnegie Papers, November, Canergie Endowment for International Peace: Washington DC 2011. Accessed on 11/12/2018 at: https://carnegieendowment.org/files/aiding_governance.pdf

4. Grindle MS Good Governance: The Inflation of an Idea. HKS Faculty Research Working Paper Series, RWP10-023, John F. Kennedy School of Government, Harvard University, 2011. Accessed on 11/12/2018 at: https://dash.harvard.edu/bitstream/handle/1/4448993/Grindle_GoodGovernance.p $\underline{\mathrm{d} \text { ? }}$ sequence $=1 \&$ is Allowed $=\mathrm{y}$

5. World Bank. Sub-Saharan Africa: From Crisis to Sustainable Growth. Washington DC, World Bank, 1989. Accessed on 11/12/2018 at: http://documents.worldbank.org/curated/en/498241468742846138/pdf/multi0pag e.pdf

6. Mc Leod RW and KM Qama Agriculture Extension, Rural Development and the Food Security Challenge. Food and Agriculture Organisation, Rome 2003. Accessed on 11/12/2018 at: http://www.fao.org/3/a-y5061e.pdf

7. Food and Agriculture Organization (FAO). Good Food Security Governance: The Crucial Premise to the Twin Track Approach - Background Paper. ESA Workshop held in Rome on 5-6 December, FAO. 2011.

8. Paarlberg RL Governance and Food Security in an Age of Globalization: Food, Agriculture and the Environment. Discussion Paper 36. International Food Policy Research Institute, Washington DC, 2002. Accessed on 11/12/2018 at: http://www.oda-alc.org/documentos/1307636457.pdf

9. Nyanjom O Devolution in Kenya's New Constitution. Society for International Development. Constitution Working Paper No. 4, the Regal Press Kenya LT, Nairobi, 2011. Accessed on 11/12/2018 at: http://sidint.net/docs/WP4.pdf

10. Thomas DR A General Inductive Training Approach for analyzing Qualitative Evaluation Data. Amer. J. Evaluation 2006; 2: 237-246. 


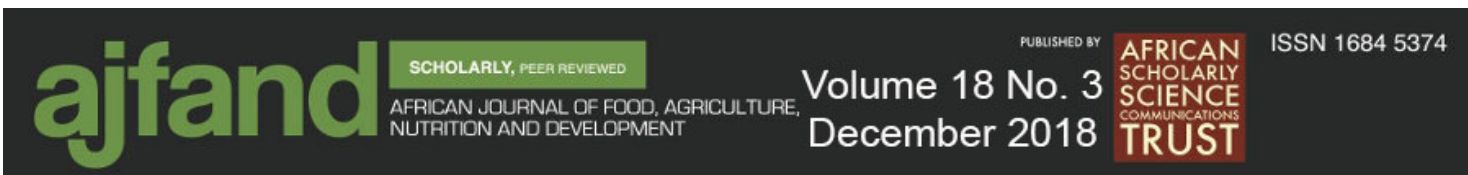

11. Kenya Demographic and Health Survey (KDHS). Kenya National Bureau of Statistics. Ministry of Health, National Aids Control Council, Kenya Medical Research Institute, National Council for Population and Development, Nairobi Kenya and The DHS Program, ICF International Maryland, USA, 2008/2009.

12. Kenya Demographic and Health Survey (KDHS). Kenya National Bureau of Statistics. Ministry of Health, National Aids Control Council, Kenya Medical Research Institute, National Council for Population and Development, Nairobi Kenya and The DHS Program, ICF International Maryland, USA, 2014.

13. von Grebmer K, Bernstein J, Brown T, Prasai N, Yohannes Y, Towey O, Foley C, Patterson F, Sonntag A, Zimmermann $\mathbf{S}$ and $\mathbf{N}$ Hossain Global Hunger Index: The Inequalities of Hunger. International Food Policy Research Institute, Concern Worldwide, Welthungerhilfe; Washington DC/Dublin/Bonn, 2017.

14. M'Kaibi FK, Steyn NP, Ochola SA and L Du Plessis The relationship between agricultural biodiversity, dietary diversity, household food security, and stunting of children in rural Kenya. F. Scien. Nutr. 2017; 5(2): 243-254.

15. Republic of Kenya. Challenges and Opportunities for Sustainable Food Security in Kenya. Department of Crops Management, Ministry of Agriculture, Kenya, 2012; 2-18.

16. Food and Agriculture Organisation, International Fund for Agriculture Development United Nations Children's Fund, and World Food Programme and World Health Organization. The State of Food Security and Nutrition in the World; Building Resilience for Peace and Food Security. Rome, FAO, 2017.

17. Brownhill L and GM Hickey Using interview triads to understand the barriers to effective food security policy in Kenya: a case study application. Food Sec. 2012; 4: 369-380.

18. Economic Commission for Africa. Land Tenure Systems and their Impacts on Food Security and Sustainable Development in Africa. ECA/SDD/05/09, 2004; 4950 .

19. Odeny E, Leonhard R, Borras SJ and M Rocha Land Grabbing in Kenya and Mozambique; A report on two research missions and a human rights analysis of land grabbing. FIAN International and RAPDA, 2010.

20. Sundet G and E Moen Political Economy Analysis of Kenya. Technical Report 19/2009 Discussion, Norwegian Agency for Development Cooperation (Norad), Dar es Salaam and Oslo, 2009; 2: 4-13.

21. Holden ST and H Ghebru Land tenure reforms, tenure security and food security in poor agrarian countries: Causal linkages and research gaps. J. Glob. Food. Sec. 2016; 10:21-28. 


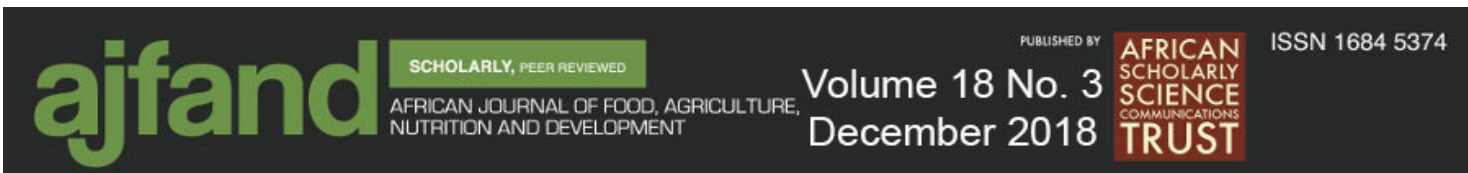

22. Ghimire KB Regional Perspectives on Land Reform: Considering the Role of Civil Society Organizations In Ghimire KB (ed) Whose Land? Civil Perspectives on Land Reform and Rural Poverty Reduction: Regional Experiences from Africa, Asia and Latin America. UNRIDS, Geneva. 2001;13-55.

23. Heidhues F, Atsain A, Nyangito $\mathbf{H}$, Padilla $\mathbf{M}$, Ghérsi $\mathbf{G}$ and $\mathbf{J}$ Le Vallèe Development Strategies and Food and Nutrition Security in Africa - An Assessment. 2020 Discussion Paper 38. International Food Policy Research Institute, Washington DC. 2004.

24. Poulton C and K Kanyinga The Politics of Revitalising Agriculture in Kenya. Future Agricultures Working Paper 059, 2013. https://assets.publishing.service.gov.uk/media/57a08a2440f0b6497400044a/FAC _Working_Paper_059.pdf

25. Miruka MK, Okello JJ, Kirigua VO and FM Murithi The role of Kenya Agricultural Research Institute (KARI) in the attainment of household food security in Kenya: A policy and organizational review. Food. Sec. 2012; 4: 341354.

26. The Food Security Act, 2014 - Kenya Law 2014. Accessed on 11/12/2018 at http://kenyalaw.org/kl/fileadmin/pdfdownloads/bills/2014/TheFoodSecurityBill2 014.pdf

27. Republic of Kenya National Food and Nutrition Security Policy: Latest draft, June 2011. Accessed on 11/12/2018 at: https://extranet.who.int/nutrition/gina/sites/default/files/KEN\%202011\%20Natio nal $\% 20$ Food $\% 20$ and $\% 20$ Nutrition $\% 20$ Security $\% 20$ Policy $\% 5$ B $1 \% 5$ D.pdf

28. The Constitution of Kenya (Kenya) 27 August, 2010. Accessed on 11/12/2018 at: https://www.refworld.org/docid/4c8508822.html

29. Hickey GM, Pelletier B, Brownhill L, Kamau GM and IM Maina Preface: Challenges and opportunities for enhancing food security in Kenya. Food Sec. 2012; 4: 333-340.

30. Food and Agriculture Organisation, International Fund for Agriculture Development and World Food Programme. The State of Food Insecurity in the World 2014; Strengthening an enabling environment for Food Security and Nutrition. Rome, FAO, 2014.

31. Rocha C Food Insecurity as Market Failure: A Contribution from Economics. $J$. Hung. Environ. Nutr. 2007; 1(4): 5-22.

32. von Braun $\mathbf{J}$ Addressing the food crisis; governance, market functioning and investment in public goods. J. Food. Sec. 2009; (1): 9-15. 


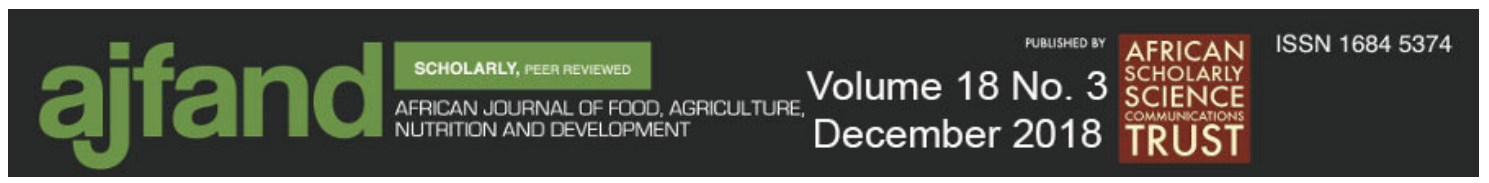

33. Haug R and EC Rauan Operationalizing the Right to Food in Africa. Noragric Report No. 2b, Agricultural University of Norway, 2001: 4-9.

34. Crosta N, Jackson D, Valenti $\mathbf{L}$ and $\mathbf{C}$ Pace Local Development and MDGs: What Role for Local Governments. Conference Framing Paper: Global Forum on Local Development, Kampala, Uganda. 2010; 8-13.

35. Cabinet Secretary for Agriculture, Livestock and Fisheries The Status of Food Security in the Country of Kenya: Memorandum to National Security Advisory Council (NSAC). 2014. 